\title{
PENERAPAN PERANGKAT PEMBELAJARAN IPA DENGAN PENDEKATAN SCIENTIFIC PADA POKOK BAHASAN PENCEMARAN LINGKUNGAN UNTUK MELATIHKAN THINKING SKILLS SISWA MI DI LAMONGAN
}

\author{
${ }^{1}$ Ummu Khairiyah, ${ }^{2}$ Mudzaki Risma, ${ }^{3}$ Muhammad Sigit Prasetyo \\ ${ }^{1,2,3}$ Universitas Islam Lamongan \\ e-mail: ${ }^{1}$ ummukhairiyah@unisla.ac.id, ${ }^{2}$ mudzakirisma20@gmail.com, \\ sigitsingit03@gmail.com
}

\begin{abstract}
This study aims to determine students' thinking skills (critical thinking skills) after using learning tools with a scientific approach. This study was carried out on 12 students SDN Tenggerejo 2 Kedungpring Lamongan. technique of collecting data by providing pretest and posttest questions. This study usesthe design of the one group pretest posttest. The results show that there is an increase in students' critical thinking skills after learning with a scientific approach.
\end{abstract}

Keywords: scientific approach, Critical Thinking skills.

\section{A. Pendahuluan}

Rasional pengembangan kurikulum 2013 salah satunya adalah adanya tantangan eksternal yang dihadapi dunia pendidikan, yang antara lain berkaitan dengan tantangan masa depan dan kompetensi yang diperlukan masa depan. Tantangan masa depan meliputi globalisasi, masalah lingkungan hidup, perkonomian,dll. Sedangkan kompetensi yang dibutuhkan untuk masa depan beberapa diantaranya adalah kemampuan berkomunikasi, kemampuan berpikir jernih dan kritis, kemampuan mempertimbangkan segi moral dalam permasalahan, dan kemampuan dalam hidup bermasyarakat yang mengglobal.

Abad 21 menuntut sumber daya manusia yang berkualitas sehingga mampu bersaing dalam persaingan global. Sumber daya manusia yang berkualitas berasal dari proses pendidikan yang berkualitas juga, dimana dalam proses pendidikan tersebut siswa dibekali dengan keterampilan-keterampilan guna memecahkan masalah, mencari alternatif solusi pemecahan masalah, dan berpikir reflektif serta evaluatif. Keterampilan-keterampilan tersebut merupakan keterampilan-keterampilan berpikir yang meliputi keterampilan berpikir kritis dan kreatif. Keterampilan berpikir merupakan salah satu kecakapan hidup yang perlu dikembangkan melalui proses pendidikan. Keterampilan berpikir sangat penting untuk membekali siswa bersaing di dunia global. Adapun dalam penelitian ini fokus mengamati kemampuan berpikir kritis siswa.

Materi IPA yang mempelajari tentang objek dan fenomena alam merupakan hal yang tidak bisa dipisahkan dari keterampilan berpikir. Hal ini 
disebabkan karena mempelajari objek dan fenomena alam dapat dipahami melalui proses berpikir kritis dan kreatif

Pendidikan dasar merupakan jenjang pendidikan yang melandasi pendidikan ketingkat yang lebih tinggi. Kualitas pembelajaran di tingkat dasar harus diperbaiki dan ditingkatkan lagi agar pondasi pendidikan menjadi kuat lagi. Dalam perbaikan pembelajaran pendidikan dasar salah satunya harus diterapkan strategi dan pendekatan pembelajaran yang lebih efektif untuk meningkatkan potensi yang dimiliki siswa ketika berada di kelas.

Berdasarkan hasil observasi dalam proses pembelajaran IPA diperoleh data bahwa hasil kegiatan pembelajaran tidak optimal. Tingkat keaktifan para siswa cukup rendah, terlihat dari kurangnya antusiasme siswa dalam bertanya sehingga dapat dikatakan bahwa proses berpikir siswa belum berjalan dengan baik. Hal tersebut salah satunya disebabkan oleh guru yang masih menggunakan metode ceramah dan menulis di papan tulis serta memberikan soal. Ceramah guru menuntut siswa untuk mendengarkan saja sehingga siswa cenderung pasif hanya mencatat apa yang di sampaikan guru tanpa ada respon balik terhadap apa yang dicatat atau disampaikan oleh guru. Karena itu, proses pembelajaran IPA disekolah hendaknya menekankan pada pemberian pengalaman secara langsung untuk mengembangkan kompetensi agar siswa dapat memahami alam disekitar secara ilmiah

Salah satu pendekatan pembelajaran yang diasumsikan dapat mengakomodir kebutuhan tumbuh kembang siswa adalah pendekatan Scientific. Pendekatan Scientific merupakan pendekatan atau suatu pembelajaran yang alamiah karena pembelajaran tersebut memiliki tahapan-tahapan untuk mengembangkan pengetahuan dan keterampilan, serta sikap peserta didik. Menurut Daryanto (2014) Penerapan pendekatan Scientific dalam pembelajaran melibatkan keterampilan proses seperti mengamati, mengklasifikasi, mengukur, meramalkan, menjelaskan, dan menyimpulkan. Sehingga melalui pendekatan Scientific diharapkan peserta didik mampu melatih thinking skills (keterampilan berpikir). Adapun langkah-langkah pendekatan Scientific yang juga merupakan indikator berpikir kritis yang diukur dalam penelitian ini adalah sebagai berikut:

Tabel 1. Langkah pendekatan Scientific dan indikator keterampilan berpikir kritis

\begin{tabular}{cccc}
\hline No & Langkah-langkah & $\begin{array}{c}\text { Keterampilan } \\
\text { berpikir kritis }\end{array}$ & $\begin{array}{c}\text { Sub keterampilan } \\
\text { berpikir kritis }\end{array}$ \\
\hline 1 & $\begin{array}{c}\text { Mengamati dan } \\
\text { mencoba }\end{array}$ & interpretasi & klasifikasi \\
\hline 2 & Menalar/ asosiasi & Analisis & Analisis data \\
\hline 3 & mengkomunikasikan & Eksplanansi & presentasi \\
\hline
\end{tabular}


Dalam pendekatan ini peserta didik sebagai subjek pembelajaran dan guru sebagai fasilitator, semua berorientasi kepada siswa. Namun, bantuan guru juga diperlukan untuk bisa memberikan stimulus agar peserta didik dapat mengasah keterampilan berpikir, selain itu hasil akhir yang diperoleh mampu meningkatkan dan menyeimbangkan agar menjadi manusia yang baik, serta memiliki kecakapan dan pengetahuan.

\section{B. Metode}

Penelitian ini dilakukan di SDN Tenggerejo 1 Kedungpring berjumlah 12 siswa kelas $\mathrm{V}$. Teknik pengumpulan data dengan menggunakan tes (tes keterampilan berpikir kritis) yang berbentuk tes tulis. Materi yang digunakan dalam penelitian adalah pencemaran lingkungan. Pada materi pencemaran lingkungan, indikator berpikir kritis yang digunakan adalah menanya untuk mempertanyakan suatu argument atau fenomena, analisis, dan komunikasi (presenting argument).

Jenis penelitian ini adalah praeksperimen dengan one group pretes posttest design (Creswell, 2016). Penelitian ini dimulai dengan pembelajaran dengan cara konvensional (pembelajaran yang selama ini dilakukan oleh guru) dan memberikan tes yang memuat keterampilan berpikir kritis. Selanjutnya menggunakan pendekatan Scientific dalam pembelajaran pada kelas yang sama kemudian diberi soal pretest dengan menggunakan instrument yang sama. Adapun desain penelitian ini sebagai berikut

\section{Keterangan:}

\begin{tabular}{lll}
\hline $\mathrm{O} 1$ & $\mathrm{X}$ & $\mathrm{O} 2$ \\
\hline
\end{tabular}

O1 : pengamatan awal (pretest) dengan metode konvensional

$\mathrm{O} 2$ : pengamatan akhir (pretest) dengan pendekatan Scientific

$\mathrm{X}$ : pembelajaran dengan model pembelajaran Scientific

Data yang diperoleh selanjutnya dianalisis dengan menggunakan paired samples $t$ test untuk mengetahui perbedaan kemampuan berpikir siswa dengan metode konvensional dan pendekatan Scientific. Analisis statistik terhadap data dilakukan dengan SPP versi 25.

\section{Hasil dan Pembahasan}

Materi pencemaran lingkungan merupakan materi yang dapat dilakukan dengan cara melakukan praktikum sesuai dengan tahap-tahap dari pendekatan Scientific. Sehingga dengan kegiatan praktikum dapat memberi kesempatan pada siswa untuk melatih kemampuan berpikir terhadap fenomena yang diberikan. Adapun perbedaan kemampuan berpikir siswa pretest dan posttest dapat dilihat pada Gambar 1 berikut. 


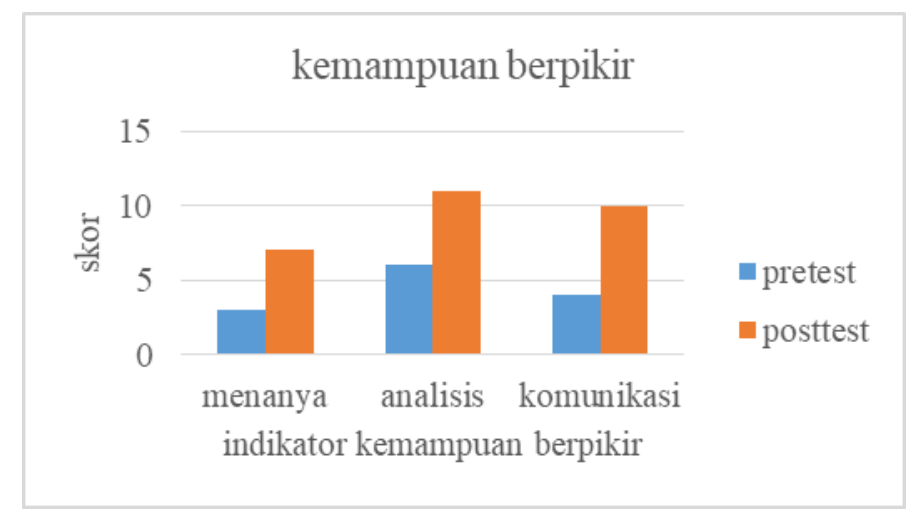

Gambar 1. Grafik skor tes pretest dan posttest

Berdasarkan grafik tersebut diketahui bahwa kemampuan berfikir siswa setelah menggunakan perangkat pembelajaran dengan pendekatan Scientific mengalami peningkatan. Langkah-langkah pendekatan Scientific dapat menstimulasi siswa dalam mempertanyakan suatu ide atau suatu fenomena. Langkah-langkah percobaan mendorong siswa untuk berpikir kritis mulai dari penyusunan hipotesis sampai dengan mengomunikasikan. Analisis data yang dilakukan juga meningkatkan proses berpikir kritis dengan menghubungkan hasil percobaan dengan teori yang relevan.

Pendekatan Scientific yang digunakan dalam pembelajaran IPA sesungguhnya memfasilitasi siswa dalam memahami sains melalui proses sains yaitu dengan keterampilan proses sains. Ini berarti siswa memperoleh informasi secara ilmiah melalui penemuannya sendiri (Karar, 2012). Langkah yang kedua dalam pembelajaran dengan pendekatan Scientific adalah menanya. Dengan mengajukan pertanyaan, siswa dapat dikatakan memiliki rasa ingin tahu yang lebih banyak. Sesuai dengan pendapat Chin (2002) bahwa mengajukan pertanyaan menandakan bahwa seseorang telah berpikir dan membantunya untuk menghasilkan idea atau pemahaman baru. Pendekatan Scientific dalam pembelajaran mendorong siswa untuk berpikir kritis terhadap fenomena yang ditampilkan dan memikirkan mengapa demikian dan berupa untuk mencari solusinya.

Langkah terakhir pada pendekatan Scientific adalah mengkomunikasikan. Teori Vygotski menyatakan bahwa konstruksi pengetahuan terjadi jika dilakukan secara bersama dalam bentuk kolaboratif sehingga terjadi tukar gagasan antara individu yang disesuaikan dengan konteks social budaya siswa dalam pembelajaran. Yeong, (2014) dalam penelitiannya menegaskan apabila siswa dilatihkan keterampilan berfikir (thinking skills), maka mereka nantinya akan dapat membantu memecahkan masalah dalam kehidupan nyata. Grozdanka, et al (2014) mengemukakan bahwa berpikir kritis merupakan salah satu indikator dari peningkatan kualitas pendidikan. Tingginya kemampuan berpikir kritis menandakan bahwa siswa mempunyai kualitas yang baik. Keterampilan berpikir ini sangat diperlukan siswa dalam semua jenjang pendidikan. 


\section{Simpulan}

Hasil penelitian yang diperoleh, di dapatkan data bahwa kemampuan berpikir siswa (berpikir kritis) sebelum menerapkan perangkat pembelajaran dengan pendekatan Scientific dan sesudah menerapkan perangkat pembelajaran dengan pendekatan Scientific diperoleh perbedaan yang signifikan. Pembelajaran dengan pendekatan Scientific menjadi salah satu alternatif untuk meningkatkan keterampilan berpikir kritis karena langkah-langkahnya dapat melatih mahasiswa dalam mengembangkan proses berpikir tersebut. Perlu dilakukan penelitian dengan menggunakan pendekatan Scientific untuk keterampilan berpikir lainnya.

\section{Daftar Rujukan}

Chin, C. (2002). Student-Generated Questions: Encouraging Inquisitive Minds in Learning Science. Teaching and Learning, 23(1), 59-67.

Creswell, J. W. (2016). Research Design Pendekatan Metode Kulaitatif, Kuantitatif dan Campuran. Yogyakarta: Pustaka Pelajar.

Daryanto. (2014). Pembelajaran Pendekatan Scientific Kurikulum 2013. Yogyakarta: Gava Media.

Grozdanka Gojkovab, Aleksandar Stojanovićab, A. G. R. (2014). Critical Thinking Of Students - Indicator Of Quality In Higher Education. Procedia - Social and Behavioral Sciences.

Karar, E. E. \& N. Y. (2012). The investigation of scientific process skill level of elementary education 8th grade students in view of demographic features. 38853889. Procedia Social and Behavioral Sciences.

Yeong, foong may. (2014). Science students and the social siences. Higher Education Research and Development, 33(5), 1078-1080. 